\title{
Investigation of Critical Genetic Variations of Vitamin D Metabolism and Vitamin D Serum Levels in Brain Cancer
}

\author{
D Vitamini Serum Düzeyleri ile D Vitamini Metabolizmasındaki Kritik Genlere \\ Ait Varyasyonların Beyin Kanserinde İncelenmesi
}

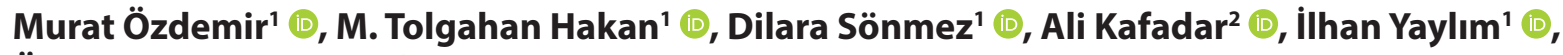 Özlem Küçükhüseyin ${ }^{1}$}

'Department of Molecular Medicine, Istanbul University Aziz Sancar Institute of Experimental Medicine, Istanbul, Turkey 2Department of Neurosurgery, Istanbul University-Cerrahpasa Medical Faculty, İstanbul, Turkey ORCID ID: M.Ö. 0000-0002-4081-7096; M.T.H. 0000-0002-0622-7148; D.S. 0000-0002-4962-5330; A.K. 0000-0002-3312-3192;
I.Y. 0000-0003-2615-0202; Ö. K. 0000-0001-6298-5026

Cite this article as: Özdemir M, Hakan MT, Sönmez D, Kafadar A, Yaylım I, Küçükhüseyin Ö. Investigation of Critical Genetic Variations of Vitamin D Metabolism and Vitamin D Serum Levels in Brain Cancer. Experimed 2020; 10(1): 16-24.

\begin{abstract}
Recent studies imply the effects of micronutrient intake on the development of several cancers including primary brain cancer (PBC). The biological effects of vitamin D, a member of the fat-soluble vitamin family acting as a steroid hormone, was carried out by binding its receptor (VDR) through vitamin D-binding-protein (VDBP). The present study aims to investigate the effects of vitamin D levels and VDR rs2228570, VDR rs731236, VDBP 7041 polymorphisms on PBC development. The study group consisted of 71 patients and 84 controls. Vitamin D levels were determined by high-pressure liquid chromatography where polymorphisms by polymerase-chain-reaction and restriction fragment length polymorphism methods. The distribution of VDR rs2228570 variants in $\mathrm{PBC}$ and its subgroups were determined as FF $>\mathrm{Ff}>\mathrm{ff}$; VDBP rs7041 variants were TG $>$ GG $>$ TT, however, VDR rs731236 variants were $\mathrm{Tt}>\mathrm{TT}>\mathrm{tt}$ in $\mathrm{PBC}$ and meningioma and $\mathrm{TT}>\mathrm{Tt}>\mathrm{tt}$ in glioma. Vitamin $D$ levels were measured below normal levels in all patients and control groups, which shows the deficiency in Turkish society in line with the literature. Our results show that low serum vitamin D level may be an individual risk factor in the development of brain tumors, however, VDR rs2228570 and rs731236 and VDBP rs7041 polymorphisms have no effect on the risk of disease development.
\end{abstract}

Keywords: Brain tumors, glioma, meningioma, VDR, VDBP, vita$\min D$

\section{öz}

Son çalışmalar, mikrobesin alımının primer beyin kanseri (PBC) dahil olmak üzere çeşitli kanser türlerinin gelişimi üzerindeki etkilerine işaret etmektedir. Yağda çözünen vitaminler sınıfında yer alan ve steroid hormon olarak etki gösteren $D$ vitamini biyolojik etkilerini reseptörü (VDR) ile vitamin D bağlayıcı protein (VDBP) aracıllğıyla gerçeklestirmektedir. Çalışmamızda, D vitamini düzeyleri ile VDR rs2228570, VDR rs731236, VDBP 7041 polimorfizmlerinin PBC gelişimi üzerindeki etkilerinin araştırı ması amaçlanmıştır. Çalışma grubu, beyin kanseri tanısı konmuş 71 hasta ile 84 sağlıklı bireyden oluşturulmuştur. D vitamini düzeyi, yüksek basınçlı sıvı kromatografisi yöntemiyle, VDR Fokl (rs2228570), Taql (rs731236) ve VDBP rs7041 polimorfizmleri polimeraz zincir reaksiyonu ve restriksiyon parça uzunluk polimorfizmi yöntemleriyle belirlenmiştir. Çalışmamızda VDR Fokl gen varyantlarına ait dağılım primer beyin kanseri ve alt gruplarında FF>Ff $>$ ff; VDBP rs7041 varyantları TG $>$ GG $>$ TT olarak, VDR Taql varyantlarının ise primer beyin kanseri ve meningiomada $\mathrm{Tt}>\mathrm{TT}>\mathrm{tt}$, gliomada $\mathrm{TT}>\mathrm{Tt}>\mathrm{tt}$ olduğu tespit edilmiştir. D Vitamini düzeyleri tüm hasta gruplarında ve kontrol grubunda normal düzeyinin altında ölçülmüş, bu durum Türk toplumundaki vitamin D düzeylerinin literatürle uyumlu bir şekilde düşük seviyede olduğunu göstermiştir. Çalışmamız sonuçları, beyin tümörleri gelişiminde düşük serum $D$ vitamini seviyesinin bireysel bir risk faktörü olabileceğini, ancak VDR rs2228570 ile rs731236 ve VDBP rs7041 polimorfizmlerinin hastalık gelişim riskine etkisinin olmadığını göstermektedir.

Anahtar Kelimeler: Beyin tümörleri, glioma, meningioma, VDR, VDBP, D vitamini 


\section{INTRODUCTION}

Brain tumors account for $1.8 \%$ of all cancers worldwide and constitute $2.3 \%$ of cancer-related deaths (1). Although primary brain tumors possess very heterogeneous pathological mechanisms, the contribution of genetic factors to the development of brain tumors is not completely understood. Recent studies focus on identifying genetic factors in the risk of cancer development due to its importance in choosing appropriate individual cancer treatment strategies (2). Besides, studies investigating the relationship between micronutrient intake and cancer development also attract attention. In fact, vitamin D and its metabolites have been shown to be associated with various types of cancer due to their direct potential to impair proliferative capacity of cancer cells and their anti-cancerogenous and toxic effects on cancer cells (3).

Vitamin $D$ is a member of the fat-soluble vitamin family, and acts as a steroid hormone rather than a vitamin because it is incorporated into the systemic circulation to effect the target tissue and its circulating amount is regulated by feedback mechanisms. Vitamin $D$ is taken either directly through nutrition or is endogenously synthesized in the body, however, active form of vitamin D synthesis occurs in two different tissues as liver and kidneys. Both of the skin synthesized and the dietary forms of vitamin D are converted to 25-Hydroxy Vitamin D (25- $(\mathrm{OH})$ $D$ ) in the liver, which is the result of the first hydroxylation. The half-life of $25-(\mathrm{OH}) \mathrm{D}$ is $2-3$ weeks and its serum level is 1000 times greater than its biologically active form, 1,25-Dihydroxy Vitamin $\mathrm{D}\left(1,25-(\mathrm{OH})_{2} \mathrm{D}\right)$ metabolite. Thus, $25-(\mathrm{OH}) \mathrm{D}$ is the best measurement parameter for consideration of serum vitamin $D$ levels. The second hydroxylation of $25-(\mathrm{OH}) \mathrm{D}$ metabolites by the 1 alpha hydroxylase enzyme in the kidney leads to the formation of the active form of vitamin $\mathrm{D}, 1,25-(\mathrm{OH})_{2} \mathrm{D}(4)$.

The biological effect of vitamin $\mathrm{D}$ is carried out by binding its membrane-bound receptor (VDR) through vitamin D binding protein (VDBP). The direct effects, also known as non-genomic effects of vitamin $D$ is driven by interacting with VDR. The engagement with VDR activates intracellular secondary messengers which leads normal serum levels of calcium and phosphate, regulation of osteoblastic functions and bone resorption $(4,5)$. On the other hand, transcription factors mediate the genomic effects as cell proliferation, differentiation, and apoptosis as well as DNA repair and oxidative stress (5-7).

VDR required for vitamin $D$ function has been shown to be present in more than 50 tissues including the central nervous system (CNS) cells as microglia, astrocyte, oligodendrocyte cells and peripheral nervous system (PSS) cells as Schwann cell nuclei which affects the metabolism of brain cells $(6,8,9)$. In vitro studies in microglia cells confirmed the metabolisation of 25$(\mathrm{OH}) \mathrm{D}$ to $1,25-(\mathrm{OH})_{2} \mathrm{D}$ in the brain (10). On the other hand, it is well-known in vitamin D metabolism that, 24-hydroxylase (CY$P 24 A 1)$ inactivates the active form of vitamin $D$ by converting it to $1,24,25-(\mathrm{OH})_{3} \mathrm{D}$ in a dose dependent manner. In fact, it was shown in rat primary glia cells that the expression of CYP24A1
mRNA was increased with the excess amounts of $1,25-(\mathrm{OH})_{2} \mathrm{D}$, which points the regulation of vitamin D levels in the brain (11).

VDR protein is a member of the nuclear receptor family. Several polymorphic sites have been identified on VDR gene. Among the most common VDR gene polymorphisms on chromosome $12 q 13$ which alters the binding capacity of active vitamin $D$ to VDR, Fokl (rs2228570) and Taql (rs731236) attract attention. rs2228570 polymorphism on exon 2 leads an amino acid substitution [thymine $(\mathrm{T}) \rightarrow$ Cytosine $(\mathrm{C})$ ] that alters the transcriptional activity of VDR protein by formation of two different translation initiation region. As for rs 731236 polymorphism on exon 9 a $\mathrm{T}$ to $\mathrm{C}$ alternation occurs and results in a synonymous transformation (isoleucine $\rightarrow$ isoleucine) that affects the mRNA levels of VDR protein $(6,12-15)$.

VDBP, another important molecule in vitamin D metabolism, is a glycoprotein acting in various biological functions as fatty acid transportation, chemotaxis and macrophage activation (7). Several polymorphic sites have been identified on VDBP gene localized on chromosome 4q11-q13 including rs7041 and rs4588. Both polymorphisms of VDBP was responsible for the alteration of binding affinity and/or carrying capacity of VDBP that affects vitamin D serum levels (16).

Previous studies reported that the disorders of vitamin D metabolism play a central role in the pathogenesis of various diseases by affecting cell homeostasis and growth. Besides, the effects of VDR gene polymorphisms on various types of carcinomas such as breast, prostate and colon have been widely studied $(6,12,13)$. The present study aims to investigate the effects of VDR rs2228570, rs731236, and for the first time VDBP rs7041 polymorphisms and serum levels of vitamin $D$ on the risk of primary brain cancer development in Turkish society

\section{MATERIAL AND METHOD}

\section{Participants}

The study group comprised of 71 primary brain cancer patients followed by Istanbul University-Cerrahpasa Medical Faculty, Department of Neurosurgery and 84 healthy volunteers with no signs and no family history of any malignancy.

The present study conformed with the Helsinki Declaration. All participants in the study signed their written consent prior to the study. The blood samples were taken only with written informed consent. The study protocol was also approved by the local ethical committee (Decree No: 2017/1480) and the Research Fund of Istanbul University (Project Number:TYL-2018-28203).

\section{Measurement of Serum Vitamin D Levels}

High-Performance Liquid Chromatography (HPLC) technique was used to measure the serum vitamin D levels. HPLC system (Spectra System, Thermo Scientific, USA). RP C18 analytical column $250 \times 4.6 \mathrm{~mm}, 5 \mu \mathrm{m}$ particle size (Knauer, Berlin, Germany) was used to separate the analytes. The detection was performed with a UV detector by using commercial vitamin D measurement kit and bi-level controls [Chromogen Grafelfing, Germany] 
according to the manufacturer's instructions (flow rate $=0.7 \mathrm{ml}$ / min; column temperature $=25^{\circ} \mathrm{C}$; wavelength $=265 \mathrm{~nm}$ ).

\section{Genotyping}

Genomic DNA (gDNA) was isolated by a commercial DNA purification kit (Jena Bioscience, Jena, Germany). gDNA was amplified by polymerase chain reaction (PCR) and the genotypes were analyzed with restriction fragment length polymorphism (RFLP) method as previously reported (12-17). Table 1 shows the PCR-primer sequences of rs2228570, rs731236 and rs7041 polymorphisms. The PCR products were 272 base pairs (bp) for VDR Fokl, 347 bp for VDR Taql and 482 bp for VDBP rs7041. Genotyping was performed by RFLP method with Fokl, Taql and Haelll endonuclease restriction enzymes. The fragments were then viewed under UV light after staining with ethidium bromide. The fragments of VDR Fokl polymorphism were $272 \mathrm{bp}$ for wild type homozygous (FF) genotype and 198+74 bps for mutant (ff) genotype; VDR Taql were 347 bp for wild type homozygous (TT) genotype and $293+54$ bps for mutant (tt) genotype.; VDBP rs7041 were 482 bp for wild type homozygous (TT) genotype and 298+184 bps for mutant (GG) genotype.

\section{Statistical Analysis}

Statistical analysis was performed using the SPSS software package (revision 21.0; SPSS Inc., Chicago, IL, USA). Chi-Square (x2) test and Student's t-test or One-Way Anova test were used to compare the frequency of gene variants and identify the effects on the biochemical activity, respectively. $p<0.05$ was
Table 1. The PCR primer sequences of VDR and VDBP gene polymorphisms.

\begin{tabular}{|c|c|}
\hline SNP & Primer sequence \\
\hline \multirow{2}{*}{$\begin{array}{l}\text { VDR rs:2228570 } \\
\text { (Fokl) }\end{array}$} & 5'-GATGCCAGCTGGCCCTGGCACTG-3' \\
\hline & 5'-ATGGAAACACCTTGCTTCTTCTCCCTC-3' \\
\hline \multirow{2}{*}{$\begin{array}{l}\text { VDR rs:731236 } \\
\text { (Taql) }\end{array}$} & 5'-CAGAGCATGGACAGGGAGCAAG-3' \\
\hline & 5'-GCAACTCCTCATGGGCTGAGGTCTCA-3' \\
\hline \multirow{2}{*}{ VDBP rs:7041 } & 5'-AAATAATGAGCAAATGAAAGAAGAC-3' \\
\hline & 5'-TCTACTCATTTCTTTGCTGTTATTG-3' \\
\hline
\end{tabular}

SNP: single nucleotide polymorphism

considered as statistical significance. The relative risk determination was estimated by calculating odds ratio (OR) and confidence intervals. Allele frequencies were made according to the gene counting technique. The figures were obtained by using GraphPad Prism 6.0 (San Diego, CA, USA).

\section{RESULTS}

The study groups were age and sex matched ( $p>0.05$ ). The control group comprised of $63.1 \%$ females and $36.9 \%$ males with $49.3 \%$ females, and $50.7 \%$ males in the patient group. The mean age was $40.14 \pm 13.18$ in the control group, and $42.00 \pm 13.43$ in the patient group. The baseline of the patients group was shown in Table 2. Among the glioma and meningioma patients

Table 2. Baseline characteristics of the patients group.

\begin{tabular}{|c|c|c|c|}
\hline Clinical features & $\begin{array}{l}\text { Primary Brain Tumors } \\
\qquad(n=71)\end{array}$ & $\begin{array}{l}\text { Glioma Cases } \\
\quad(n=40)\end{array}$ & $\begin{array}{l}\text { Meningioma Cases } \\
\qquad(n=31)\end{array}$ \\
\hline \multicolumn{4}{|l|}{ Tumor Histology (n,\%) } \\
\hline Astrocytoma + Oligoastrocytoma & $53(75.0 \%)$ & $30(75.0 \%)$ & - \\
\hline Oligodendroglioma & $18(25.0 \%)$ & $10(25.0 \%)$ & - \\
\hline \multicolumn{4}{|l|}{ Tumor Grade (n,\%) } \\
\hline Grade I & $25(35.8 \%)$ & $5(12.1 \%)$ & $22(69.5 \%)$ \\
\hline Grade II & $22(30.4 \%)$ & $16(39.4 \%)$ & $5(17.4 \%)$ \\
\hline Grade III & $14(19.6 \%)$ & $9(24.2 \%)$ & $4(13.1 \%)$ \\
\hline Grade IV & $10(14.3 \%)$ & $10(24.3 \%)$ & - \\
\hline \multicolumn{4}{|l|}{ Tumor Localization (n,\%) } \\
\hline Right Hemisphere & $36(51.1 \%)$ & $22(53.3 \%)$ & $4(11.7 \%)$ \\
\hline Left Hemisphere & $32(44.7 \%)$ & $18(46.7 \%)$ & $14(47.1 \%)$ \\
\hline Midline & $3(4.3 \%)$ & - & $13(41.2 \%)$ \\
\hline \multicolumn{4}{|l|}{ Necrosis Pathology $(n, \%)$} \\
\hline present & $38(52.9 \%)$ & $21(52.9 \%)$ & - \\
\hline absent & $33(47.1 \%)$ & $19(47.1 \%)$ & - \\
\hline \multicolumn{4}{|l|}{ Vascular Endothelial Proliferation (n,\%) } \\
\hline present & $56(78.9 \%)$ & 32 (78.9\%) & - \\
\hline absent & $15(21.1 \%)$ & $8(21.1 \%)$ & - \\
\hline
\end{tabular}


group, the frequency of cases with advanced tumor grade (III + IV) was lower than early-stage patients (I + II) $(48.5 \% \rightarrow 51.5 \%$ and $13.0 \% \rightarrow 87.0 \%$, respectively), as well as primary brain can$\operatorname{cer}(66.1 \% \rightarrow 33.9 \%)$ (data not shown).

The genotype and allele frequencies of VDR rs2228570 and rs731236 and VDBP rs7041 polymorphisms in primary brain cancer patients, meningioma and glioma cases, and controls were shown in Table 3. No significant relations were found between the risk of primary brain cancer and VDR or VDBP polymorphisms ( $p>0.05)$. The difference between VDR rs2228570, rs731236 or VDBP rs7041 variants and clinical parameters of primary brain tumors (Table 4) and glioma or meningioma (data not shown) were also not significant ( $p>0.05$ ).

Figure 1 shows the comparison of vitamin $D$ (25-hydroxyvitamin $D, 25-(\mathrm{OH}) \mathrm{D})$ serum levels among the study groups. The means of serum $25-(\mathrm{OH}) \mathrm{D}$ levels in primary brain cancer, glioma and meningioma patients versus controls were 14.33 \pm 1.20 $\mathrm{ng} / \mathrm{ml},(\mathrm{p}=0.042), 13.09 \pm 1.69 \mathrm{ng} / \mathrm{ml}(\mathrm{p}=0.039), 15.74 \pm 1.66 \mathrm{ng} /$ $\mathrm{ml}(\mathrm{p}>0.05)$ and $18.75 \pm 1.81 \mathrm{ng} / \mathrm{ml}$, respectively. However, no significant differences were observed between vitamin $D$ serum levels and clinical parameters as sex, necrosis pathology, vascular endothelial proliferation, sex and advanced or early tumor grades (data not shown, $\mathrm{p}>0.05$ ).
The serum levels of 25-(OH)D among VDR rs2228570, rs731236 and VDBP rs7041 variants in primary brain cancer patients and controls were shown in Figure 2. The difference in the levels of vitamin D among VDR and VDBP variants was not significant, except heterozygous VDR Fokl genotype, $\mathrm{Ff}(\mathrm{p}=0.047)$.

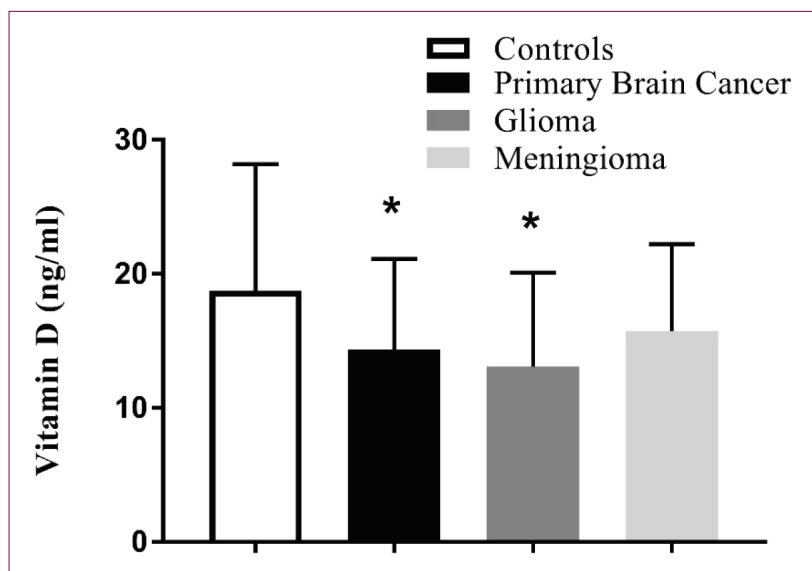

Figure 1. Serum levels of $25-(\mathrm{OH}) \mathrm{D}$ in the study groups. Unpaired student's t test was used to estimate the difference between the groups.

Table 3. The distribution of VDR rs 2228570 and rs731236, and VDBP rs7041 genotypes and alleles in the whole study groups.

\begin{tabular}{|c|c|c|c|c|c|}
\hline \multicolumn{2}{|c|}{$\begin{array}{l}\text { Genotypes and Alleles } \\
(n, \%)\end{array}$} & \multirow{2}{*}{$\begin{array}{c}\begin{array}{c}\text { Control } \\
(\mathbf{n}=84)\end{array} \\
41(48.8 \%)\end{array}$} & \multirow{2}{*}{$\begin{array}{c}\begin{array}{c}\text { Primary Brain Tumors } \\
\text { (n=71) }\end{array} \\
37(52.1 \%)\end{array}$} & \multirow{2}{*}{$\begin{array}{c}\begin{array}{c}\text { Glioma Cases } \\
(\mathbf{n}=\mathbf{4 0})\end{array} \\
20(50.0 \%)\end{array}$} & \multirow{2}{*}{$\begin{array}{c}\begin{array}{c}\text { Meningioma Cases } \\
(\mathbf{n}=\mathbf{3 1})\end{array} \\
17(54.8 \%)\end{array}$} \\
\hline VDR rs 2228570 & $\mathrm{FF}$ & & & & \\
\hline \multirow[t]{4}{*}{ (Fokl) } & $\mathrm{Ff}$ & $32(38.1 \%)$ & $25(35.2 \%)$ & $16(40.0 \%)$ & $9(29.0 \%)$ \\
\hline & $\mathrm{ff}$ & $11(13.1 \%)$ & $9(12.7 \%)$ & $4(10.0 \%)$ & $5(16.2 \%)$ \\
\hline & F Allele & 114 (67.9\%) & 99 (69.7\%) & $56(70.0 \%)$ & $43(69.4 \%)$ \\
\hline & f Allele & $54(32,1 \%)$ & $43(30.3 \%)$ & $24(30.0 \%)$ & $19(30.6 \%)$ \\
\hline \multirow{5}{*}{$\begin{array}{l}\text { VDR rs731236 } \\
\text { (Taql) }\end{array}$} & TT & 31 (36.9\%) & $29(40.8 \%)$ & $18(45.0 \%)$ & $11(35.5 \%)$ \\
\hline & Tt & 40 (47.6\%) & $32(45.1 \%)$ & $16(40.0 \%)$ & $16(51.6 \%)$ \\
\hline & $\mathrm{tt}$ & $13(15.5 \%)$ & $10(14.1 \%)$ & $6(15.0 \%)$ & $4(12.9 \%)$ \\
\hline & T Allele & $102(60.7 \%)$ & $90(63.4 \%)$ & $52(65.0 \%)$ & $38(61.3 \%)$ \\
\hline & t Allele & 66 (39.3\%) & $52(36.6 \%)$ & $28(35.0 \%)$ & $24(38.7 \%)$ \\
\hline \multirow[t]{5}{*}{ VDBP rs7041 } & TT & 9 (10.7\%) & $8(11.3 \%)$ & 5 (12.5\%) & $3(9.7 \%)$ \\
\hline & TG & 49 (58.3\%) & $43(60.6 \%)$ & 25 (62.5\%) & $18(58.1 \%)$ \\
\hline & GG & $26(31.0 \%)$ & $20(28.2 \%)$ & $10(25.0 \%)$ & $10(32.3 \%)$ \\
\hline & T Allele & 67 (39.9\%) & 59 (41.5\%) & $35(43.7 \%)$ & $24(38.7 \%)$ \\
\hline & G Allele & 101 (60.1\%) & $83(58.5 \%)$ & $45(56.3 \%)$ & $38(61.3 \%)$ \\
\hline
\end{tabular}

Chi-square test was used to compare genotypes in the study group. For determining allele frequencies gene count method was used. n, number of individuals; $p<0.05$ denoted statistical significance. 


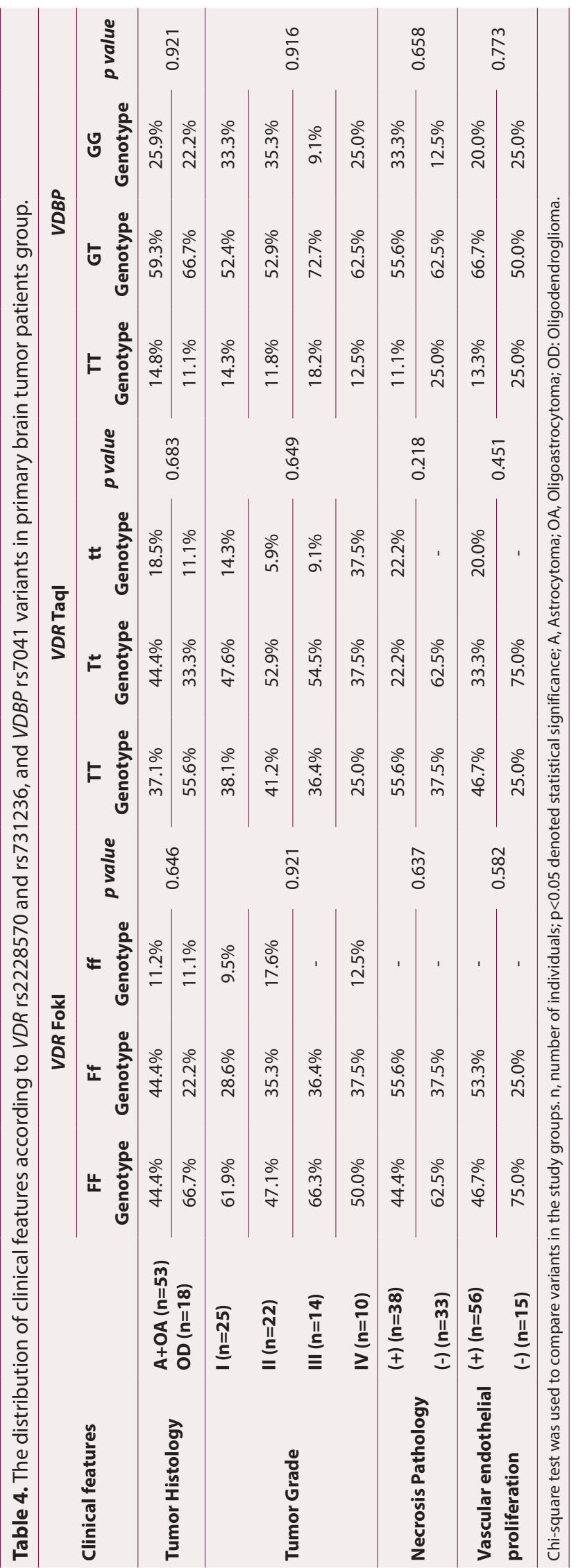

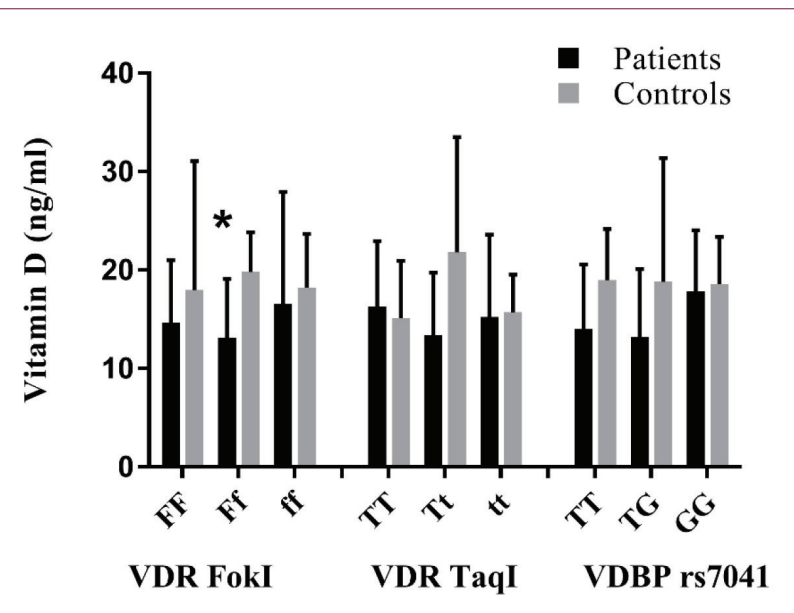

Figure 2. The serum levels of $25-(\mathrm{OH}) \mathrm{D}$ among VDR rs2228570 Fokl, rs731236 Taql and VDBP rs7041 variants in primary brain cancer patients and controls. Student's $t$ and Anova tests were used to evaluate the difference between and within the groups. *is donated as statistical significance of $F f$ genotype between primary brain cancer patients and controls.

\section{DISCUSSION}

Primary brain tumors are one of the most common types among the cancer cases in the world $(1,17)$. In Turkey, it was reported that brain cancer constitutes $\sim 2 \%$ of all cancer types in 2017 and said to be in the top 10 cancers (18). Although the exact mechanism of the formation of brain tumors was not fully understood, environmental factors such as exposure to toxic chemicals or ionizing radiation, nutritional behaviors as micronutrient intake including vitamin D and genetic predisposition are some of the risk factors for the risk of primary brain tumor development $(4,5,13)$.

Vitamin D, found in the 1800s, was shown to have important functions such as the regulation of calcium balance, bone metabolism and more recently in cancer progression and development by its genomic effects as the regulation of cell proliferation, differentiation and apoptosis, DNA repair, oxidative stress and cellular metabolism through transcription factors $(4-7,19)$. In 2008 , a report showing the evidence of the causal link between vitamin $D$ and cancer was published by the international cancer research center. Vitamin D is considered to be among the steroid hormones that regulate cell functions such as cell proliferation and differentiation. The effect of active form of vitamin $\mathrm{D}, 1,25-(\mathrm{OH})_{2} \mathrm{D}$, on cell growth and differentiation of cancer cells makes this molecule a candidate marker in the regulation of tumor cells (20). Several studies reported the vitamin D-inhibition of proliferation and differentiation of malignant cells in various tissues such as breast, colon, skin, lung and brain (3,21-29). It has been conducted that high levels of 25-(OH)D, a vitamin D storage form, are associated with low incidence in various types of cancer $(3,21-29)$. In fact, Shi 
et al. showed lower levels of $25-(\mathrm{OH}) \mathrm{D}(<20 \mathrm{ng} / \mathrm{ml})$ in $71.6 \%$ of patients diagnosed with breast cancer (25). Mezawa et al. reported significant relationships between colorectal cancer and vitamin D insufficiency (26). Moreover, Atoum et al. reported a 19.2 fold increased risk with vitamin $D$ insufficiency $(<10 \mathrm{ng} / \mathrm{ml})$ in colorectal cancer patients (15). On the other hand, in a meta-analysis on optimal serum $25-(\mathrm{OH}) \mathrm{D}$ levels to protect from colorectal cancer, Gorham et al. reported that colorectal patients with optimal $25-(\mathrm{OH}) \mathrm{D}(33 \mathrm{ng} / \mathrm{ml})$ serum levels possess $50 \%$ decreased cancer risk compared to patients with $\leq 12 \mathrm{ng} /$ $\mathrm{mL} 25-(\mathrm{OH}) \mathrm{D}$ (27). In contrast to these studies, in a case-control study among 200 patients diagnosed with lung cancer and a control group of 400 people conducted by Gromowski et al., the average $25-(\mathrm{OH}) \mathrm{D}$ levels of lung cancer patients has been reported as $17.1 \mathrm{ng} / \mathrm{ml}$ while it was $17.2 \mathrm{ng} / \mathrm{ml}$ in the controls, and the study concluded as serum vitamin D levels do not affect the development of lung cancer (28).

Ogus et al. evaluated the serum vitamin D levels in the Turkish population and reported the average vitamin $D$ levels as $22.80 \pm 13.27 \mathrm{ng} / \mathrm{ml}(22.49 \pm 13.88 \mathrm{in}$ women, $23.73 \pm 10.57 \mathrm{ng} /$ $\mathrm{ml}$ in men). According to their study conducted on 2012, at least $24 \%$ of women, $29 \%$ of men and $25 \%$ of the whole population have optimal serum vitamin D levels (29). In our study, the mean 25-(OH)D level of the control group consisting of 84 people was measured as $18.75 \pm 1.81 \mathrm{ng} / \mathrm{ml}$, while it was $14.33 \pm 1.20 \mathrm{ng} / \mathrm{ml},(p=0.042)$ in primary brain cancer patients, $13.09 \pm 1.69 \mathrm{ng} / \mathrm{ml}(\mathrm{p}=0.039)$ in glioma patients and $15.74 \pm 1.66$ $\mathrm{ng} / \mathrm{ml}(\mathrm{p}>0.05)$ in meningioma patients. Holick et al. classified vitamin D levels as deficient $(<20 \mathrm{ng} / \mathrm{ml})$, insufficient $(21-29$ $\mathrm{ng} / \mathrm{ml}$ ) and adequate (> $30 \mathrm{ng} / \mathrm{ml}$ ) (30). Accordingly, vitamin $D$ deficiency is observed in the entire study group, since both the control group and the patient group have $25-(\mathrm{OH}) \mathrm{D}$ levels below $20 \mathrm{ng} / \mathrm{ml}$. Our results are compatible with Ogus et al. (29). Despite contradictory reports related to Vitamin D and cancer risk in the literature, in our study, when evaluated for primary brain cancer and its subgroups, glioma and meningioma, our results revealed that vitamin $D$ levels may have an independent effect on primary brain cancer and glioma development.

The biological effect of vitamin $D$ was triggered by binding its specific receptor, VDR. While VDR is an important molecule in multiple pathways such as insulin growth factor (IGF), it also involves in inflammation and estrogen-related pathways that may be associated with cancer prognosis (3). In many studies, the effect of VDR gene polymorphisms has been shown in the development of various cancer types including breast, brain, prostate and colorectal cancer $(3,6,12-15,18-28)$. One of the common VDR gene polymorphisms in exon 2 is Fokl (rs2228570) polymorphism which leads in an alternative transcription initiation site by the substitution of cytosine (C) thymine ( $T$ ) and alters the activity of the VDR protein. On the other hand, in Taql (rs731236) polymorphism of exon 9, another well-known polymorphism, a $\mathrm{T} \rightarrow \mathrm{C}$ nucleotide substitution (ATT $\rightarrow$ ATC) leads to a silent mutation (isoleucine $\rightarrow$ isoleucine) in codon 352 affecting the secondary structure of the RNA transcript (12-15). Studies have reported that VDRs localized in neuronal and glial cells affect the metabolism of brain cells and alter VDR expression (31,32).

The potential effect of vitamin D on cancer treatment was first described in myeloid leukemia cells (33), and latter synthetic vitamin $D$ analogs have been proposed for use in the treatment of central nervous system tumors. In fact, phase II clinical trials have been associated with the positive effects of vitamin $D$ treatment on glioblastoma cells (33-36). It has been reported that increased vitamin $D$ production in glioma cells after treatment may regulate cell proliferation (31). Many studies have also noted the effect of VDR polymorphisms on various types of cancer.

In the case-control study of Moossavi et al., VDR-FokI (rs2228570) ff genotypes ( $\mathrm{OR}=4.31,95 \% \mathrm{Cl}: 2.99-6.22, \mathrm{p}=0.0001$,) and $\mathrm{f}$ allele $(\mathrm{OR}=4.83,95 \% \mathrm{Cl}$ : $0.99-23.8, \mathrm{p}=0.035)$ were found to have a high risk of colorectal cancer (37). Yilmaz et al. reported no association between brain cavity and VDR-Fokl variants in pediatric brain cancer patients diagnosed with malignant brain tumor (38). In study of Tang et al. conducted with 5284 cases and 7500 control groups in Europe, a significant increase in breast cancer risk and VDR-Fokl polymorphism variants was reported (39). Toptas et al. reported a positive correlation between meningioma patients and VDR-Fokl variants in brain cancer patients $(p=0.004)$ in contrast to glioma patients $(p>0.05)(3)$. In the present study, the relationship between polymorphisms in VDR Fok-I and Taq-I and brain cancer risk was evaluated. The distribution of genotype variants of VDR Fokl polymorphism in primary brain tumors and its sub-groups, glioma and meningioma were found as FF> Ff> ff, respectively. The order of genotype frequencies in the control group was similar to that of the patient group. No significant association was found between VDR Fokl polymorphism and brain cancer development. Besides, the serum levels of 25-(OH)D does not correlate with VDR Taql genotypes in patients and control groups except Ff genotype which was found to be lower in brain cancer patients. Our results partially comply with the results of previous studies $(3,38)$. Our findings indicate that, in meningioma patients, contrary to the study of Toptas, there is no relationship between the development of meningioma and rs2228570 variants; however, our results in glioma patients are similar to those of Toptas (3) and Yilmaz (38) et al.. Since this different result may be related to the inadequate number of specimens belonging to the meningioma patient group, which is the subtype of primary brain cancers in our study group, it may be useful to re-examine the number of patients by expanding the number of the samples and the experiments in which the situation comprise the primary limitation of our study for detection of the risks in cancer subgroups.

In the study of Toptas et al. which was conducted on patients diagnosed with brain cancer in the Turkish population, VDRTaql (rs731236) polymorphism variants were also examined in meningioma and glioma patients. The findings stated that there was no significant relationship ( $p>0.05)$ (3). Similarly, the 
study of Yilmaz et al. found no association between brain tumors and VDR-Taql polymorphism variants in pediatric brain cancer patients (38). In colorectal cancer patients, Moossavi et al. also showed any significant difference for VDR-Taql variants (37). In contrast to these studies, Tang et al. reported a significant relationship between breast cancer and VDR-Taql, Bsml and Apal polymorphisms variants (39). In the study of Chen et al. published in 2018, the distribution of VDR-Taql polymorphism in prostate cancer indicated that there was an association with Asians and especially with Japanese population (40). In our study, while the order of VDR Taql variants was found as $\mathrm{Tt}>\mathrm{TT}>\mathrm{tt}$ in primary brain cancer and meningioma patients, and $\mathrm{TT}>\mathrm{Tt}>\mathrm{tt}$ in glioma patients vs Tt $>\mathrm{TT}>\mathrm{tt}$ in controls, no relation was found between VDR Taql variants and primary brain cancer, glioma and meningioma patients. In addition, the lack of a significant relationship between the $25-(\mathrm{OH})$ vitamin D level and the VDR Taql gene variants indicates that there is no relationship between VDR Taq polymorphism and brain cancer.

VDBP, which plays a very important role in vitamin D metabolism, is a glycoprotein that carries vitamin $D$ metabolites in the blood. VDBP, which is high in the blood, is required to carry vitamin $D$ to many tissues and prevent the occurrence of various diseases $(7,16)$. Although VDBP has been shown to have more than 120 variants, two important phenotypic alleles have been widely studied as VDBP rs7041 which causes an amino acid change (aspartic acid $\rightarrow$ glutamic acid) in codon 416 and VDBP rs4588 causes threonine to lysine change in codon 420 $(7,16,14)$. Zhou et al. reported no association between VDBP rs7041 polymorphism and gastrointestinal, colorectal, gastric, esophageal and hepatocellular cancers (14). In contrast, Baykara et al. indicated a significant relation with lung cancer (41), as Anderson et al. in breast cancer (42). In our study, VDBP rs7041 distribution was found as TG> GG> TT. GG> TT in the whole patients' groups and controls. Our results showed any association between VDBP rs7041 polymorphism and the risk of the development of brain tumors similar to several reports in the literature. On the other hand, the lack of any association between VDBP variants and vitamin D serum levels indicates the existence of no correlation with brain tumors. To our knowledge, our findings of VDBP rs7041 are the first results in brain tumors in Turkish population which fills the gap in this subject.

Prospective and retrospective studies in the literature indicates that $25-(\mathrm{OH}) \mathrm{D}$ levels lower than $20 \mathrm{ng} / \mathrm{ml}$ increase the mortality rates by $50 \%$ in several cancer types (43). Low life expectancy was also indicated in patients diagnosed with cancer due to vitamin D deficiency. Vitamin D, of which the levels were affected by dietary habits, exposure to sunlight, seasonal changes, sex, age, malabsorption disorder, and the use of certain medications that affect absorption, has different survival roles in vital mechanisms through its blood levels via genomic and non-genomic functions as acting as anti-inflammatory, anti-oxidant, as well as playing part in DNA damage repair, apoptosis, autophagic cell death, anti-proliferation and differentiation $(4,5,19,20,44)$.

\section{CONCLUSION}

In conclusion, our results showed that polymorphisms in the vitamin D receptor (rs2228570 and rs731236) and binding protein (rs7041) have no effect on the development and prognosis of brain tumors. However, lower serum levels of vitamin D may be an independent risk factor for the development of glioma and primary brain cancer. On the other hand, in line with the literature, vitamin D levels in Turkish society were low as it was measured below normal levels as $<20 \mathrm{ng} / \mathrm{mL}$ in both patient group and control group.

Ethics Committee Approval: Ethics committee approval was received for the study from Istanbul University (Decree No: 2017/1480).

Peer-review: Externally peer-reviewed.

Author Contributions: Concept - Ö.K., M.Ö., İ.Y.; Data Collection and/ or Processing - A.K., M.Ö. D.S.; Analysis and/or Interpretation - Ö.K., I.Y., M.T.S.; Literature Search Ö.K., M.Ö., D.S.; Writing - Ö.K., I.Y.; Critical Reviews - Ö.K., I.Y., A.K., M.T.H.

Conflict of Interest: The authors have no conflict of interest to declare.

Financial Disclosure: The present study was supported by a grant from the Scientific Research Projects Coordination Unit of Istanbul University (Project No: TYL-2018-28203).

Etik Komite Onayı: Çalışma için İstanbul Üniversitesi Etik Kurul'undan onay alınmıştır (Karar No: 2017/1480).

Hakem Değerlendirmesi: Dış bağımsız.

Yazar Katkıları: Fikir - Ö.K., M.Ö., I.Y.; Veri Toplanması ve/veya İşlemesi A.K., M.Ö. D.S.; Analiz ve/veya Yorum - Ö.K., I.Y., M.T.S.; Literatür Taraması - Ö.K., M.Ö., D.S.; Yazan - Ö.K., I.Y.; Eleştirel İnceleme - Ö.K., I.Y., A.K., M.T.H.

Çıkar Çatışması: Yazarlar çıkar çatışması bildirmemişlerdir.

Finansal Destek: Bu çalışma, İstanbul Üniversitesi Bilimsel Araştırma Projeleri Koordinasyon Birimi tarafından desteklenmiştir (Proje No: TYL2018-28203).

\section{REFERENCES}

1. Araştırma UK. Dünyadaki Beyin Kanseri Vakası ve ölüm İstatistiği 2012 [updated 27.04.2018. Available from: http://globocan.iarc.fr/ Pages/fact_sheets_population.aspx?country $=900$.

2. Rajaraman P, Melin BS, Wang Z, McKean-Cowdin R, Michaud DS, Wang SS, et al. Genome-wide association study of glioma and meta-analysis. Human Genetics 2012; 131(12): 1877-88. [CrossRef]

3. Toptaş B, Kafadar AM, Cacina C, Turan S, Yurdum LM, Yiğitbaşı N, et al. The vitamin $D$ receptor (VDR) gene polymorphisms in Turkish brain cancer patients. BioMed Research International 2013; 2013. [CrossRef]

4. Christakos S, Ajibade DV, Dhawan P, Fechner AJ, Mady LJ. Vitamin D: metabolism. Endocrinology and Metabolism Clinics 2010; 39(2): 243-53. [CrossRef]

5. Deeb KK, Trump DL, Johnson CS. Vitamin D signalling pathways 
in cancer: potential for anticancer therapeutics. Nature Reviews Cancer 2007; 7(9): 684. [CrossRef]

6. Cornet A, Baudet C, Neveu I, Baron-Van Evercooren A, Brachet P, Naveilhan P. 1, 25-dihydroxyvitamin D3 regulates the expression of VDR and NGF gene in Schwann cells in vitro. Journal of Neuroscience Research 1998; 53(6): 742-6. [CrossRef]

7. Gomme PT, Bertolini J. Therapeutic potential of vitamin D-binding protein. Trends in Biotechnology 2004; 22(7): 340-5. [CrossRef]

8. Burkert $R, M c G r a t h ~ J$, Eyles $D$. Vitamin $D$ receptor expression in the embryonic rat brain. Neuroscience Research Communications 2003; 33(1): 63-71. [CrossRef]

9. Baas D, Prüfer K, Ittel ME, Kuchler-Bopp S, Labourdette G, Sarliève $\mathrm{LL}$, et al. Rat oligodendrocytes express the vitamin D3 receptor and respond to 1, 25-dihydroxyvitamin D3. Glia 2000; 31(1): 5968. [CrossRef]

10. Boontanrart M, Hall SD, Spanier JA, Hayes CE, Olson JK. Vitamin D3 alters microglia immune activation by an IL-10 dependent SOCS3 mechanism. Journal of Neuroimmunology 2016; 292: 126-36. [CrossRef]

11. Naveilhan P, Neveu I, Baudet C, Ohyama K, Brachet P, Wion D. Expression of $25(\mathrm{OH})$ vitamin D3 24-hydroxylase gene in glial cells. Neuroreport 1993; 5(3): 255-7. [CrossRef]

12. Delanghe JR, Speeckaert R, Speeckaert MM. Behind the scenes of vitamin $D$ binding protein: more than vitamin $D$ binding. Best Practice \& Research Clinical Endocrinology \& Metabolism 2015; 29(5): 773-86. [CrossRef]

13. Sweeney C, Curtin K, Murtaugh MA, Caan BJ, Potter JD, Slattery ML. Haplotype analysis of common vitamin $D$ receptor variants and colon and rectal cancers. Cancer Epidemiology and Prevention Biomarkers 2006; 15(4): 744-9. [CrossRef]

14. Köstner K, Denzer N, Mueller CS, Klein R, Tilgen W, Reichrath J. The relevance of vitamin $D$ receptor (VDR) gene polymorphisms for cancer: a review of the literature. Anticancer Research 2009; 29(9): 3511-36.

15. Zhou L, Zhang X, Chen X, Liu L, Lu C, Tang X, et al. GC Glu416Asp and Thr420Lys polymorphisms contribute to gastrointestinal cancer susceptibility in a Chinese population. International Journal of Clinical and Experimental Medicine 2012; 5(1): 72.

16. Atoum MF, Tchoporyan MN. Association between circulating vitamin D, the Taq1 vitamin D receptor gene polymorphism and colorectal cancer risk among Jordanians. Asian Pac J Cancer Prev 2014; 15(17): 7337-41. [CrossRef]

17. Miyazaki T, Ishikawa E, Matsuda M, Akutsu H, Osuka S, Sakamoto $\mathrm{N}$, et al. Assessment of PD-1 positive cells on initial and secondary resected tumor specimens of newly diagnosed glioblastoma and its implications on patient outcome. Journal of Neuro-Oncology 2017; 133(2): 277-85. [CrossRef]

18. Bakanlığı TS. Kanser İstatistikleri 2017 [updated 27.04.2018. Available from: http://kanser.gov.tr/Dosya/2017Haberler/2017_4_subat.pdf.

19. Mohr SB. A brief history of vitamin D and cancer prevention. Annals of Epidemiology 2009; 19(2): 79-83. [CrossRef]

20. Holick MF. Vitamin D status: measurement, interpretation, and clinical application. Annals of Epidemiology 2009; 19(2): 73-8. [CrossRef]

21. Öğüş E, Sürer H, Kılınç A, Fidancı V, Yılmaz G, Dindar N, et al. D Vitamini düzeylerinin aylara, cinsiyete ve yaşa göre değerlendirilmesi. Ankara Medical Journal 2014; 15(1). [CrossRef]

22. Grant WB. A critical review of Vitamin D and cancer: A report of the IARC Working Group on vitamin D. Dermato-Endocrinology 2009; 1(1): 25-33. [CrossRef]

23. Bertone-Johnson ER, Chen WY, Holick MF, Hollis BW, Colditz GA,
Willett WC, et al. Plasma 25-hydroxyvitamin D and 1, 25-dihydroxyvitamin D and risk of breast cancer. Cancer Epidemiology and Prevention Biomarkers 2005; 14(8): 1991-7. [CrossRef]

24. Lowe LC, Guy M, Mansi JL, Peckitt C, Bliss J, Wilson RG, et al. Plasma 25 -hydroxy vitamin $D$ concentrations, vitamin $D$ receptor genotype and breast cancer risk in a UK Caucasian population. European Journal of Cancer 2005; 41(8): 1164-9. [CrossRef]

25. Tworoger SS, Lee I-M, Buring JE, Rosner B, Hollis BW, Hankinson SE. Plasma 25-hydroxyvitamin D and 1, 25-dihydroxyvitamin D and risk of incident ovarian cancer. Cancer Epidemiology and Prevention Biomarkers 2007; 16(4): 783-8. [CrossRef]

26. Garland CF, Mohr SB, Gorham ED, Grant WB, Garland FC. Role of ultraviolet $B$ irradiance and vitamin $D$ in prevention of ovarian cancer. American Journal of Preventive Medicine 2006; 31(6): 512-4. [CrossRef]

27. Shi L, Nechuta S, Gao Y-T, Zheng Y, Dorjgochoo T, Wu J, et al. Correlates of 25-hydroxyvitamin $D$ among Chinese breast cancer patients. PLoS One 2014; 9(1): e86467. [CrossRef]

28. Mezawa H, Sugiura T, Watanabe M, Norizoe C, Takahashi D, Shimojima $A$, et al. Serum vitamin D levels and survival of patients with colorectal cancer: post-hoc analysis of a prospective cohort study. BMC Cancer 2010; 10(1): 347. [CrossRef]

29. Gorham ED, Garland CF, Garland FC, Grant WB, Mohr SB, Lipkin M, et al. Optimal vitamin $D$ status for colorectal cancer prevention: a quantitative metaanalysis. American Journal of Preventive Medicine 2007; 32(3): 210-6. [CrossRef]

30. Gromowski T, Gapska P, Scott RJ, Kąklewski K, Marciniak W, Durda $\mathrm{K}$, et al. Serum $25(\mathrm{OH}) \mathrm{D}$ concentration, common variants of the VDR gene and lung cancer occurrence. International Journal of Cancer 2017; 141(2): 336-41. [CrossRef]

31. Garcion E, Wion-Barbot N, Montero-Menei CN, Berger F, Wion D. New clues about vitamin $D$ functions in the nervous system. Trends in Endocrinology \& Metabolism 2002; 13(3): 100-5. [CrossRef]

32. Bhanushali AA, Lajpal N, Kulkarni SS, Chavan SS, Bagadi SS, Das BR. Frequency of fokl and taql polymorphism of vitamin $D$ receptor gene in Indian population and its association with 25-hydroxyvitamin D levels. Indian Journal of Human Genetics 2009; 15(3): 108. [CrossRef]

33. Cplston K, Colston MJ, Feldman D. 1, 25-dihydroxyvitamin D3 and malignant melanoma: the presence of receptors and inhibition of cell growth in culture. Endocrinology 1981; 108(3): 1083-6. [CrossRef]

34. Naveilhan P, Berger F, Haddad K, Barbot N, Benabid AL, Brachet $P$, et al. Induction of glioma cell death by 1, 25 (OH) 2 vitamin D3: towards an endocrine therapy of brain tumors? Journal of Neuroscience Research 1994; 37(2): 271-7. [CrossRef]

35. Baudet $C$, Chevalier G, Naveilhan P, Binderup L, Brachet $P$, Wion D. Cytotoxic effects of 1a, 25-dihydroxyvitamin D3 and synthetic vitamin D3 analogues on a glioma cell line. Cancer Letters 1996; 100(1-2): 3-10. [CrossRef]

36. Trouillas P, Honnorat J, Bret P, Jouvet A, Gerard J-P. Redifferentiation therapy in brain tumors: long-lasting complete regression of glioblastomas and an anaplastic astrocytoma under long term 1-alpha-hydroxycholecalciferol. Journal of Neuro-oncology 2001; 51(1): 57-66. [CrossRef]

37. Moossavi M, Parsamanesh N, Mohammadoo-Khorasani M, Moosavi M, Tavakkoli T, Fakharian T, et al. Positive correlation between vitamin D receptor gene Fokl polymorphism and colorectal cancer susceptibility in South-Khorasan of Iran. Journal of Cellular Biochemistry 2018; 119(10): 8190-4. [CrossRef]

38. Yilmaz B, Tokuc GA, Koc A, Yesil E. Investigation of vitamin D recep- 
tor gene polymorphism in pediatric patients with brain cancer. Indian journal of medical and paediatric oncology: official journal of Indian Society of Medical \& Paediatric Oncology 2017; 38(2): 128.

39. Tang C, Chen N, Wu M, Yuan H, Du Y. Fok1 polymorphism of vitamin $D$ receptor gene contributes to breast cancer susceptibility: a meta-analysis. Breast Cancer Research and Treatment 2009; 117(2): 391. [CrossRef]

40. Chen L, Wei J, Zhang S, Lou Z, Wang X, Ren Y, et al. Association of VDR gene Taql polymorphism with the susceptibility to prostate cancer in Asian population evaluated by an updated systematic meta-analysis. Onco Targets and Therapy. 2018; 11: 3267. [CrossRef]

41. Baykara O, Erşen E, Batur Ş, Buyru N. Role of vitamin D binding pro- tein (VDBP) gene polymorphisms in lung cancer. Turkish Journal of Thoracic and Cardiovascular Surgery 2017; 25(4). [CrossRef]

42. Anderson LN, Cotterchio M, Cole DE, Knight JA. Vitamin D-related genetic variants, interactions with vitamin $D$ exposure, and breast cancer risk among Caucasian women in Ontario. Cancer Epidemiology and Prevention Biomarkers 2011; 20(8): 1708-17. [CrossRef]

43. Giovannucci E. The epidemiology of vitamin $D$ and cancer incidence and mortality: a review (United States). Cancer Causes \& Control 2005; 16(2): 83-95. [CrossRef]

44. Jeon S-M, Shin E-A. Exploring vitamin D metabolism and function in cancer. Experimental \& Molecular Medicine 2018; 50(4): 20. [CrossRef] 